AGRO-INDUSTRI

Vol. 3 No. 2 ; November 2016

\title{
PENGARUH FORMULASI PENAMBAHAN TEPUNG SUKUN DALAM PEMBUATAN MIE KERING
}

\author{
"RIZKI AMALIA ${ }^{1}$, AK QOYUM FINARIFI ${ }^{1}$ \\ ${ }^{1}$ Jurusan Teknologi Industri Pertanian, Politeknik Negeri Tanah Laut, Jl. A. Yani, Km. 6, Ds. \\ Panggung, kec. Pelaihari, kab Tanah Laut, Kalimantan Selatan
}

Naskah diterima : 30 September 2016 ; Naskah disetujui : 28 Oktober 2016

\begin{abstract}
ABSTRAK
Program penganekaragaman pangan dari buah sukun dilakukan sebagai salah satu cara untuk memanfaatkan buah sukun yang berlimpah pada musim panen dan mengembangkan produk pangan. Salah satu upaya penganekaragaman sukun yaitu pembuatan tepung sukun sebagai formulasi penambahan dalam proses pembuatan mie kering. Tujuan dari penelitian ini adalah optimasi formulasi penambahan tepung sukun dalam pembuatan mie kering. Analisa terhadap mie kering dilakukan dengan uji organoleptik dan kadar air. Hasil uji organoleptik diolah menggunakan uji ANOVA yang dilanjutkan dengan uji DMRT. Hasil pengolahan data menunjukkan bahwa mie kering perlakuan terbaik adalah $100 \mathrm{~g}$ tepung sukun dan $900 \mathrm{~g}$ tepung terigu dengan suhu dan waktu pengukusan $80^{\circ} \mathrm{C}$ selama 30 menit dan rata-rata kadar air $28,2 \%$.
\end{abstract}

Kata Kunci : Sukun, Tepung Sukun, Mie Kering

\section{PENDAHULUAN}

Sukun (Artocarpus communis) adalah tumbuhan dari genus Artocarpus dalam famili Moraceae yang banyak terdapat di kawasan tropika seperti Malaysia dan Indonesia. Ketinggian tanaman ini biasanya mencapai 20 meter. Sukun bukan buah bermusim meskipun biasanya berbunga dan berbuah dua kali setahun. Kulit buahnya berwarna hijau kekuningan dan terdapat segmen-segmen petak berbentuk poligonal. Segmen poligonal ini dapat menentukan tahap kematangan buah sukun (Mustafa, 1998).

Tujuan dari pembuatan tepung sukun antara lain untuk memperpanjang masa simpan, dapat disubsitusikan ke produk lain yang disukai masyarakat. Tepung sukun diperoleh dari buah sukun tua yang diolah melalui proses penepungan. Tepung sukun digunakan sebagai produk perantara karena mempunyai kandungan gizi yang tinggi sehingga dapat menunjang gizi masyarakat. Keunggulan dari pengolahan buah sukun menjadi tepung sukun adalah tepung sukun lebih praktis dan lebih mudah didistribusikan, meningkatkan daya guna, hasil guna, nilai guna, dan lebih mudah diolah menjadi produk yang memiliki nilai ekonomi tinggi, lebih mudah dicampur dengan tepungtepung dan bahan lainnya (Fatmawati, 2012).

Salah satu jenis makanan yang sangat populer dan digemari oleh masyarakat Indonesia adalah mie. Konsumsi mie sangat meningkat karena dipengaruhi oleh beberapa keunggulan yang dimiliki yaitu selain rasanya yang enak dan mudah dikunyah, penyajian mie juga cukup praktis. Dengan demikian peluang usaha industri pengolahan mie baik dalam industri skala kecil maupun besar berpontensi besar. Berdasarkan kandungan kadar air, mie dibedakan menjadi dua yaitu mie basah dan mie kering. Mie kering merupakan mie mentah yang telah dikeringkan hingga kadar

*Korespondensi:

Telp. : 081314912116

Email : ra.amalia.rizki@gmail.com 
airnya mencapai 8 - 10\%. Pengeringan umumnya dilakukan dengan penjemuran di bawah sinar matahari, dioven, dan dapat juga dengan frying. Karena bersifat kering, maka mie ini mempunyai daya simpan yang relatif panjang dan mudah penanganannya (Nasution, 2005).

Pembuatan mie kering yang berbahan baku utama tepung terigu dapat meningkatkan ketergantungan terhadap kebutuhan tepung terigu yang semakin tinggi sehingga akan mengakibatkan kebutuhan impor gandum yang semakin tinggi pula, karena Indonesia bukan merupakan negara penghasil gandum. Sehingga diperlukan alternatif lain yaitu untuk menambahkan bahan yang memiliki fungsi sama seperti tepung terigu.

Berdasarkan penelitian ini akan dilakukan formulasi penambahan tepung sukun sebagai bahan tambahan yang dapat dicampurkan dengan tepung terigu untuk pembuatan mie kering sehingga dapat menentukan pengaruh formulasi penambahan tepung sukun yang terbaik.

\section{METODE PENELITIAN}

Bahan yang digunakan dalam penelitian ini adalah tepung sukun yang akan ditambahkan dalam pembuatan mie kering. Tepung sukun didapatkan dengan penjemuran dibawah sinar matahari, sedangkan mie kering dikeringkan dengan menggunakan oven. Parameter yang diamati akan didapatkan melalui uji organolepti dan penghitungan kadar air. Data yang didapatkan akan dianalisis dengan Analysis Of Variance (ANOVA) dan Uji Duncans Multiple Range Test (DMRT).

\section{Pelaksanaan Penelitian}

\section{Prosedur Pembuatan Tepung Sukun}

Kulit buah sukun tua dikupas dan kemudian dicuci bersih. Buah sukun yang telah dibersihkan dipotong kecil-kecil kemudian dijemur di bawah terik sinar matahari sampai benar benar kering. Potongan sukun kering ditumbuk atau digiling menggunakan alat yang bersih. Selanjutnya tepung sukun diayak sehingga menghasilkan tepung yang halus dan siap digunakan sebagai bahan penelitian.

\section{Prosedur Pembuatan Mie Kering}

Semua bahan disiapkan sesuai yang dibutuhkan kemudian dilakukan pencampuran bahan sampai homogen dengan perbandingan sebagai berikut; $0 \%$ tepung sukun $+100 \%$ tepung terigu (M1) sebagai kontrol, 10\% tepung sukun $+90 \%$ tepung Terigu (M2), dan 50\% tepung sukun + $50 \%$ tepung terigu (M3). Setelah adonan kalis, dibuat lembaran tipis adonan tersebut dimasukkan kedalam mesin pres (roll press), sehingga diperoleh lembaran adonan dengan ketebalan $2 \mathrm{~mm}$. Lembaran-lembaran tersebut kemudian dimasukkan ke dalam roll pencetak mie (stiller) yang berfungsi mengubah lembaran mie menjadi untaian mie yang bergelombang. Setelah melalui proses pencetakan dilakukan pengukusan (steaming) dengan suhu dan waktu yang bervariasi sesuai perlakuan yaitu: $60^{\circ} \mathrm{C}$ selama 20 menit, $60^{\circ} \mathrm{C}$ selama 30 menit, $60^{\circ} \mathrm{C}$ selama 40 menit, $70^{\circ} \mathrm{C}$ selama 20 menit, $70^{\circ} \mathrm{C}$ selama 30 menit, $70^{\circ} \mathrm{C}$ selama 40 menit, $80^{\circ} \mathrm{C}$ selama 20 menit, $80^{\circ} \mathrm{C}$ selama 30 menit, dan $80^{\circ} \mathrm{C}$ selama 40 menit untuk mendapatkan suhu yang standar. Untaian mie yang telah dikukus kemudian didinginkan, dan dikeringkan dengan cara dioven selama 1 jam dengan suhu $70^{\circ} \mathrm{C}$. Mie yang sudah kering kemudian dimasak dengan waktu yang sama yaitu selama 2 menit.

\section{Uji Organoleptik}

Mendapatkan pengaruh formulasi penambahan tepung sukun pada proses pengukusan (steam) mie yaitu dengan cara melakukan uji organoleptik pada masing-masing sampel dengan perlakuan yang berbeda. Uji organoleptik dilakukan dengan mengisi score sheet yang terdiri dari 
uji hedonik yaitu uji kesukaan. Panelis yang digunakan dalam uji sebanyak 15 orang yang seluruhnya terdiri dari pelajar penggemar mie.

\section{Perhitungan Kadar Air}

Uji kadar air dilakukan dengan metode pengeringan oven. Sampel mie sebelum dikeringkan ditimbang dengan berat yang sama yaitu masing-masing sebanyak 30 gram, kemudian sampel dioven selama 1 jam dengan suhu $70^{\circ} \mathrm{C}$. Mie kering sesudah dioven didinginkan kemudian ditimbang beratnya. Dilakukan perhitungan kadar air:

$$
\text { Kadar air }=\frac{\text { Beratawal- beratakhir }}{\text { Beratawal }} \times 100 \%
$$

\section{HASIL DAN PEMBAHASAN}

\section{Formulasi Tepung Sukun Dalam Pembuatan Mie Kering}

Pembuatan tepung sukun dilakukan dengan pengeringan sinar matahari. Buah sukun sebanyak $10 \mathrm{~kg}$ diolah menjadi tepung sukun dan menghasilkan tepung sukun sebanyak $2 \mathrm{~kg}$. Rendamen tepung sukun sebagai berikut :

\section{Uji Organoleptik}

$$
\begin{aligned}
\text { Rendamen }(\%) & =\frac{\text { Berat Alhir }}{\text { Berat Aws }} \times 100 \% \\
& =\frac{2 \mathrm{~kg}}{10 \mathrm{~kg}} \times 100 \% \\
& =20 \%
\end{aligned}
$$

Berdasarkan uji organoleptik yang dilakukan pada produk mie kering dengan perlakuan suhu dan waktu Pengukusan (steam) yang berbeda diperoleh hasil terbaik yaitu pada suhu $80^{\circ} \mathrm{C}$ selama 30 menit. Sehingga pada produk M1 (0\% tepung sukun $+100 \%$ tepung terigu ), M2 (10\% tepung sukun $+90 \%$ tepung Terigu ) dan M3 (50\% tepung sukun $+50 \%$ tepung terigu) dikukus pada suhu $80^{\circ} \mathrm{C}$ selama 30 menit selanjutnya dilakukan analisa Uji Anova untuk mengetahui pengaruh produk terbaik dari setiap perlakuan.

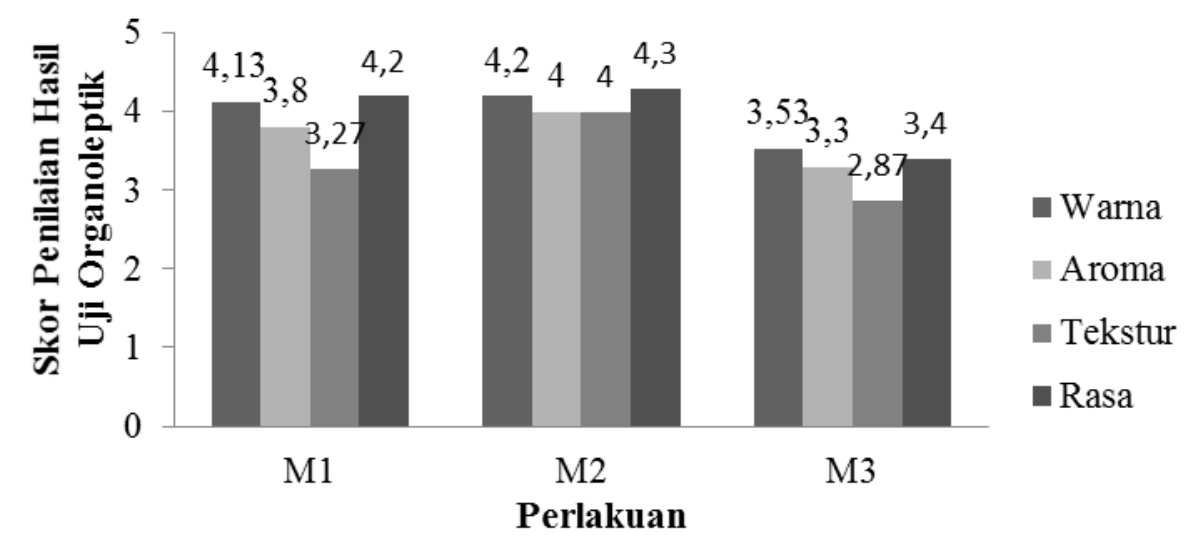

Gambar 1. Hasil Uji Organoleptik

Keterangan:

M1 : $0 \%$ tepung sukun $+100 \%$ tepung terigu

M2 : $10 \%$ tepung sukun $+90 \%$ tepung Terigu

M3 : 50\% tepung sukun $+50 \%$ tepung terigu (M3). 


\section{Formulasi Tepung Sukun Dalam Pembuatan Mie Kering}

Pengeringan pada proses pembuatan tepung sukun dilakuakan dengan metode pengeringan sinar matahari. Berat awal buah sukun sebelum dikeringkan yaitu $10 \mathrm{~kg}$ dan hasil rendamen tepung sukun yang dihasilkan adalah $20 \%$.

Proses pembuatan mie kering memiliki tiga perlakuan dimana persen penambahan tepung terigu dan tepung sukun terhadap mie berbeda-beda, yaitu produk M1 ( $0 \%$ tepung sukun $+100 \%$ tepung terigu) M2 (10\% tepung sukun $+90 \%$ tepung Terigu) dan M3 (50\% tepung sukun $+50 \%$ tepung terigu).

\section{Analisa Uji Anova dan Uji Duncan Terhadap Warna}

Warna penting bagi banyak makanan baik yang diproses maupun tidak diproses. Bersamasama dengan bau, rasa dan tekstur, warna memegang peranan penting dalam penerimaan makanan. Selain itu warna dapat memberi petunjuk mengenai perubahan kimia dalam makanan seperti pencoklatan dan karamelisasi (Anwar, 2012).

Hasil uji hedonik terhadap warna mie kering diperoleh nilai rata-rata tertinggi adalah perlakuan dengan komposisi 100 gram tepung sukun +900 gram tepung terigu dengan nilai 4,2. Dari data tersebut menunjukkan bahwa panelis lebih menyukai warna/ penampakan mie kering yang ditunjukkan oleh perlakuan dengan komposisi 100 gram tepung sukun +900 gram tepung terigu dengan hasil berwarna kuning pekat. Berdasarkan uji Anova setiap perlakuan sangat berbeda nyata dilakukan uji Duncan. Setelah dilakukan uji Duncan dapat diketahui bahwa pada tingkat kesalahan $5 \%$ dan $1 \%$ yaitu perlakuan komposisi $0 \%$ tepung sukun $+100 \%$ tepung terigu dengan perlakuan komposisi 100 gram tepung sukun +900 gram tepung terigu tidak berbeda nyata yaitu tidak ada perbedaan pengaruh antara perlakuan komposisi $0 \%$ tepung sukun $+100 \%$ tepung terigu dengan perlakuan komposisi 100 gram tepung sukun +900 gram tepung terigu. Perlakuan komposisi $0 \%$ tepung sukun $+100 \%$ tepung terigu dan perlakuan komposisi 100 gram tepung sukun +900 gram tepung terigu berbeda nyata dengan perlakuan komposisi $50 \%$ tepung sukun + $50 \%$ tepung terigu yaitu terdapat pengaruh antara perlakuan komposisi $0 \%$ tepung sukun $+100 \%$ tepung terigu, perlakuan komposisi 100 gram tepung sukun +900 gram tepung terigu dengan perlakuan komposisi 50\% tepung sukun $+50 \%$ tepung terigu. Hal tersebut dipengaruhi oleh penambahan tepung sukun, karena semakin banyak tepung sukun yang ditambahkan maka akan mempengaruhi perubahan warna mie kering yaitu warna akan semakin coklat.

\section{Analisa Uji Anova dan Uji Duncan Terhadap Aroma}

Aroma adalah salah satu faktor yang menentukan mutu dari bahan pangan, pada umumnya bau yang diterima oleh hidung dan otak lebih banyak merupakan berbagai ramuan atau campuran empat bau utama yaitu harum, asam, tengik dan hangus (Winarno, 2004). Hasil uji hedonik terhadap aroma mie diperoleh nilai rata-rata tertinggi adalah perlakuan komposisi 100 gram tepung sukun +900 gram tepung terigu dengan nilai 4. Dari data tersebut menunjukkan bahwa panelis lebih menyukai aroma mie yang ditunjukkan oleh M2 (100 gram tepung sukun + 900 gram tepung terigu). Hal tersebut karena penambahan tepung sukun yang sedikit membuat aroma mie menjadi lebih khas berbau sukun sedangkan jika penambahan tepung sukun semakin banyak akan mempengaruhi aroma mie menjadi tengik. Berdasarkan uji Anova setiap perlakuan sangat berbeda nyata sehingga dilakukan uji lanjutan yaitu uji Duncan. Setelah dilakukan uji Duncan dapat diketahui pada tingkat kesalahan 5\% dan 1\% perlakuan M1 dan M2 tidak berbeda nyata yaitu tidak ada perbedaan pengaruh antara perlakuan M1 dengan M2 sedangkan perlakuan M1, M2 berbeda 
nyata dengan perlakuan M3 yaitu terdapat pengaruh antara perlakuan M1, M2 dengan Perlakuan M3.

\section{Analisa Uji Anova dan Uji Duncan Terhadap Tekstur}

Menurut Anwar (2012), tekstur adalah penginderaan yang berhubungan dengan rabaan atau sentuhan. Kadang-kadang tekstur lebih penting dibandingkan dengan bau, rasa dan warna karena mempengaruhi citra makanan. Tekstur paling penting pada makanan lunak dan renyah. Ciri yang paling sering diacu adalah kekerasan, kekhohesifan, dan kandungan air. Tekstur adalah kehalusan suatu irisan pada saat disentuh dengan jari oleh panelis. Hasil uji hedonik terhadap tekstur mie diperoleh nilai rata-rata tertinggi adalah M2 dengan nilai 4. Dari data tersebut menunjukkan bahwa panelis lebih menyukai tekstur mie yang ditunjukkan oleh M2 (100 gram tepung sukun +900 gram tepung terigu).

Hal tersebut dipengaruhi oleh penambahan tepung sukun yang sedikit membuat mie menjadi lebih kenyal dan licin. Berdasarkan uji Anova setiap perlakuan sangat berbeda nyata sehingga dilakukan uji Duncan. Setelah dilakukan uji Duncan dapat diketahui bahwa pada tingkat kesalahan 5\% dan 1\% perlakuan M1 dengan M2 tidak berbeda nyata yaitu tidak ada perbedaan pengaruh antara perlakuan M1 dengan M2 sedangkan perlakuan M1, M2 berbeda nyata dengan perlakuan M3 yaitu terdapat pengaruh antara perlakuan M1, M2 dengan Perlakuan M3.. Perlakuan M1 dan M2 tidak berpengaruh nyata terhadap tekstur mie karena penambahan tepung sukun yang sedikit. Sedangkan pada perlakuan M3 berpengaruh nyata, karena semakin banyak tepung sukun yang ditambahkan maka mempengaruhi tekstur mie yang mudah putus dan lengket. Penambahan tepung sukun pada pembuatan mie diduga akan mempengaruhi karakteristik dari mie kering yang dihasilkan. Menurut Mendrofa (2003) penambahan tepung sukun yang terlalu banyak dalam pembuatan mi basah, menghasilkan mi basah dengan sifat yang mudah putus (kuning lentur).

\section{Analisa Uji Anova dan Uji Duncan Terhadap Rasa}

Rasa lebih banyak melibatkan panca indera lidah. Bahan makanan yang mempunyai sifat merangsang syaraf perasa akan menimbulkan perasaan tertentu. Cita rasa makanan merupakan salah satu faktor penentu bahan makanan. Makanan yang memiliki rasa yang enak dan menarik akan disukai oleh konsumen. Tekstur atau konsistensi suatu bahan akan mempengaruhi cita rasa yang dtimbulkan oleh bahan tersebut (Winarno, 2004).

Hasil uji hedonik terhadap tekstur mie diperoleh nilai rata-rata tertinggi adalah M2 dengan nilai 4,3. Dari data tersebut menunjukkan bahwa panelis lebih menyukai mie yang ditunjukkan oleh M2 (100 gram tepung sukun +900 gram tepung terigu). Hal tersebut dipengaruhi oleh kekenyalan mie karena ada penambahan tepung sukun yang sedikit membuat rasa mie enak dan disukai. Berdasarkan uji Anova setiap perlakuan sangat berbeda nyata sehingga dilakukan uji Duncan. Setelah dilakukan uji Duncan dapat diketahui bahwa pada tingkat kesalahan 5\% dan $1 \%$ perlakuan M1 dengan M2 tidak berbeda nyata yaitu tidak ada perbedaan pengaruh antara perlakuan M1 dengan M2 sedangkan perlakuan M1, M2 berbeda nyata dengan perlakuan M3 yaitu terdapat pengaruh antara perlakuan M1, M2 dengan Perlakuan M3.

\section{Perhitungan Kadar Air}

Kadar air dilakukan dengan pengeringan menggunakan metode oven. Semua sampel dioven dengan suhu $70^{\circ} \mathrm{C}$ selama 1 jam. Berdasarkan uji kadar air, rata - rata kadar air produk M1 $=36,24 \%$ lebih rendah dibandingkan M2 $=28,2 \%$ dan kadar air produk M3 $=26,17 \%$ lebih tinggi dibandingkan kadar air produk M1 dan M2. 
Kadar air (moisture) adalah bagian/contoh yang hilang jika dipanaskan pada kondisi uji tertentu. Kadar air dalam bahan makanan sangat mempengaruhi kualitas dan daya simpan dari pangan tersebut. Semakin rendah kadar air maka akan memperpanjang masa simpan produk pangan tersebut sedangkan semakin tinggi kadar air pangan umumnya semakin mudah rusak, baik karena kerusakan mikrobiologis maupun reaksi kimia.

\section{KESIMPULAN}

Berdasarkan hasil penelitian dapat disimpulkan bahwa:

1. Perlakuan penambahan tepung sukun terbaik adalah dengan perbandingan $100 \mathrm{~g}$ tepung sukun + 900 g tepung terigu, karena menghasilkan uji organoleptik terbaik dengan warna kuning pekat, aroma terbaik, tekstur kenyal dan licin, dan rasa enak

2. Untuk tujuan penyimpanan, perlakuan terbaik adalah dengan perbandingan $0 \mathrm{~g}$ tepung sukun + $1000 \mathrm{~g}$ tepung terigu, karena menghasilkan kadar air paling rendah, sehingga akan lebih tahan jika disimpan.

\section{DAFTAR PUSTAKA}

Anwar, A. dan Putri, M.P. 2012. Pengaruh Penggunaan Tepung Terigu Terhadap Sifat Sensoris Nugget Ikan Haruan. Tugas Akhir Diploma III. Program Studi Teknologi Industri Pertanian. Politeknik Tanah Laut. Hal. 14-23.

Fatmawati, T.W., 2012. Pemanfaatan Tepung Sukun Dalam Pembuatan Produk Cookies. Universitas Negeri Yogyakarta.

Mendrofa, A. 2003. Pengaruh Substitusi Tepung Sukun pada Tepung Terigu terhadap Sifat Fisik Kimiawi dan Organoleptik Mi Basah yang Dihasilkan. Skripsi. FTP UGM. Semarang.

Mustafa, A.M., 1998. Isi Kandungan Artocarpus communis, Food Science

Nasution, Z.E., 2005. Pembuatan Mie Kering Dari Tepung Terigu Dengan Tepung Rumput Laut Yang Difortifikasi Dengan Kacang Kedelai. Universitas Sumatera Utara Jl. Bioteknologi No. 1 Kampus USU Medan 20155.

Winarno, FG, 2002. Pangan, Gizi, Teknologi dan Konsumen. Jakarta : Gramedia Pustaka Utama 